\title{
The Effect of Interactive Whiteboard Applications Supported by Visual Materials on Middle School Students' Listening Comprehension and Persistence of Learning
}

\author{
Abdulkadir Kurbas \\ Kazım Karabekir Faculty of Education, Ataturk University, Turkey
}

Copyright $(2018$ by authors, all rights reserved. Authors agree that this article remains permanently open access under the terms of the Creative Commons Attribution License 4.0 International License

\begin{abstract}
In this study, it was examined how interactive whiteboard applications supported by visual materials affected middle school students' listening comprehension and persistence of learning. The sample of the study consisted of the students in the $8 / \mathrm{D}$ (experimental group) and $8 / \mathrm{H}$ (control group) cohorts of the Osman Gazi Middle School located in Palandöken central district of Erzurum province during the spring semester of the 2017-2018 school year. The study was carried out as a pre-test post-test experimental design. The data of the study were collected through the Listening Achievement Test, and t-tests were carried out to analyze the data. The reliability and validity study of the achievement test used in this study was carried out on 150 students studying in different middle schools. As a result of the analyses, the Cronbach's alpha value was found to be 0.81 and the KMO (Kaiser-Meyer-Olkin) test result was found to be 0.623 In conclusion, it was found that interactive whiteboard applications supported by visual materials were more effective in listening comprehension and persistence of knowledge according to the 2018 Turkish Course Curriculum.
\end{abstract}

Keywords 2018 Turkish Course Curriculum, Listening Comprehension, Visual Materials, Interactive Whiteboard Applications

\section{Introduction}

Technology that is increasingly influential in every field of daily life today is effective in the field of education as well, facilitating the experience of individuals in a great way. Many technological materials, even the names of which were unknown in the past century, have become indispensable parts of our lives today. These technological changes and advances have also created many opportunities in the field of education. One of the most significant tools contributed by technological an advance in the field of education is interactive whiteboard applications. Science and technological innovations ensure that pieces of information are constantly updated in terms of quantity and quality [1].

The use of diverse materials in education has increased the availability of educational opportunities, changing the function of schools, teachers and textbooks to a considerable extent. While schools are not the only environment to acquire knowledge, teachers are not the only source of information anymore, either [2]. The constructivist approach is student-centered and supports a learning process in which students are actively involved in learning activities. In this learning process, teachers only assume the role of guides. Since the constructivis approach prescribes that students are in the center and take active roles in the learning processes, they are able to use diverse materials when creating new learning products and communicating during the learning and teaching process. Technology can be used not only to facilitate students' understanding during the learning process, but also when the students create learning products and to make these products persistent. With the use of technology in learning environments, students are provided with richer learning environments, their interests are stimulated, their motivation is improved, and they are given opportunities to remember past information about subjects. Complex information presented to students who study for classes is simplified with the help of technology, and students are given opportunities to learn by living and doing [3].

The use of appropriate equipment and materials in the 
classroom supports the teacher and ensures that learning is more effective and persistent. Thus, teaching materials are increasingly more important in terms of using them to help students understand and comprehend the subjects taught during lessons, to make lessons more fun, to keep the attention of students alive, and to motivate students to learn. For this reason, textbooks and teachers have also had to constantly renew themselves in order to compete with diverse sources of information. Educational activities in contemporary models of education have strayed from the traditional school/teacher/student-centered teaching model. With new technologies that are rapidly entering our lives, education has switched to a multi-faceted and multi-channel model. With the advancement in information and educational technologies, information has begun to reach individuals through communication tools, not through schools. One of the greatest developments has taken place in interactive whiteboards within the information and education technologies. Interactive whiteboards are one of the easiest and most effective ways of accessing information. Interactive whiteboards that have been used effectively in advanced educational systems in recent years ensure the persistence of learning by providing visual materials supplemented by intelligent sounds and animations. Students can easily discuss and present their work using interactive whiteboard applications. Rephrase and join these two ideas: As students can engage interactively in the lessons, they also enjoy them more. Students who are in such high levels of interaction enjoy the lessons. Students with such enjoyment from the lessons are, then, more easily motivated during the lessons [4]; [5]; [6].

Today, the use of computers, televisions, videos, presentations and interactive whiteboards as technological possibilities enhance learning by supporting teaching in the teaching and learning process [7]. When we look at the problems in the teaching of basic language skills (reading, listening, speaking and writing) in our country, Turkey, we see that students have difficulties especially in understanding what they read and listen to. Computers and different teaching materials support Turkish teachers during the process of teaching especially abstract concepts such as listening comprehension and interpreting, and also facilitate attracting the attention of students to the lectures and increasing their interest and motivation in the topics taught [8].

Research shows that when interactive whiteboards are used in the classroom environment, they improve students' desire to learn, let teachers teach lessons more effectively, and contribute particularly to the creation of an active learning environment in collaboration with the class [9]; [10]; [11]; [12]; [13]; [14]. Interactive whiteboards are expected to replace regular books in the future due to their importance in the educational process in terms of the ability to update information easily and quickly, and are regarded as the classroom technology of tomorrow [15].

In modern classrooms teachers are able to utilize these resources when teaching abstract subjects by connecting to the internet through these interactive whiteboards. If teachers find it necessary, they are able to easily present a common subject through cameras, videos and these interactive whiteboards to people in different places simultaneously and share their ideas with subject matter experts in various places of the world [16].

One of the prerequisites for success in the educational process where technological materials are rapidly expanding is the effective use of educational technologies. Today, developed countries aiming to raise individuals who are effective in all areas of life and have the required skills have restructured their curricula based on contemporary educational technologies and improved their curricula in this direction. Thus, it is seen that the use of more advanced instructional tools in terms of quality and quantity in the educational process provides many benefits in terms of teaching a course and achieving the general and specific goals of education [17]. Our country has also kept up with this technological change in the field of education, and computers, projection devices and interactive whiteboards have started to be widely used in schools [18].

\subsection{The Place and Importance of Visual Materials in Learning}

Students in elementary and middle schools need a more concrete life than do adults. It is necessary to design instructional environments that will help students connect with the real life and acquire concrete experiences, particularly when teaching a new subject or concept. Materials used during lessons help teachers to create such educational environments [19]. The use of visual readingand presentation-based materials — which help keep students' attention vivid, contribute to students' learning as well as entertain them, in order to prevent boredom of students in a short period of time - is widely found in the Turkish Course Curriculum, especially after the 2018 curriculum change.

Diverse methods and techniques should be used in lessons to make learning more effective, not just a single method and technique. It is not possible to achieve the goals and objectives - determined by the Ministry of National Education that are targeted to be given to students - by using only a single method [20]. It is important to use more educational tools in the classroom in order for students to be able to better understand what they learn. Visual and audial tools are at the forefront in today's classroom environments. In this sense, it is an inevitable need to resort to learning environments formed by visual and auditory tools, which reach more sensory organs, in order to achieve the persistence of learning [21].

The world that depends on communication tools such as televisions and computers has made visuals to become indispensable for human life. Thus, the voice was 
overthrown from power by the image, and homo-videns (the people who see) were replaced by homo sapiens (the people who know) [22]. Individuals learn about $83 \%$ of what they learn in the learning process by visual means [23]. Especially in the middle school level, $83 \%$ of students learn through experiences acquired by seeing, $11 \%$ by hearing, $3.5 \%$ by smelling, $1.5 \%$ by touching and $1 \%$ by tasting [24]. One of the most basic methods for addressing the visual senses of a student at the middle school level is to prepare, present and display diverse visual materials. These are various images, photographs, schemas, tables, films and similar visual means. Visuals are highly likely to be influential in desire to learn. The multiplicity/inadequacy or sufficiency/insufficiency of what is learned is directly proportional to the use of visual materials. For learning activities, the most effective sense among all senses is the visual sense, which is a fact that reveals the importance of visuality. The fact that what is seen cannot easily be forgotten makes visual materials more important in terms of persistence of learning

The importance of visual materials in learning has made them appear in the objectives listed in the Turkish course. Such importance of visual materials has made them to be included in the elementary and middle school curricula. For this reason, visual reading and visual presentation were considered as a separate instructional domain in the elementary school Turkish Course Curriculum; in the middle school Turkish Course Curriculum, they were interspersed within the objectives of the field of grammar learning with listening, speaking, reading and writing skills [25].

Using visually enriched interactive whiteboard applications, smart teachers can present various visual materials that they have prepared in advance, and additionally, they can use a variety of items in lessons through the internet [26]. Interactive whiteboards enable their users to show videos and a variety of visual materials to help teach concepts, to get access to Web resources and simultaneously present them to the whole class, and to record for reuse. Interactive whiteboards give their users the opportunity to highlight videos and animations that are present in their software, audio clips, colors, images, screening, zooming in an out, and thus they transform lessons into a more visual and more vivid form. Given their features, interactive/smart boards offer teachers the opportunity to access the desired point on the visual when teaching lessons that are hard to understand and when presenting information that is hard to reach [13]. Computers, projectors and overhead projectors that are used in educational environments are indispensable tools for visual presentations. Individuals who effectively use these tools have also improved their presentation skills. With the contributions of computer technology to the visualization movement, this reality has reached an incredible dimension. When interactive whiteboards are used by teachers for a long time, they are likened to mediators in the interaction between teachers and students [27].

The Turkish Course Curriculum, as a separate learning domain, supports the domain of grammar learning through listening/observing, speaking, reading, and writing skills. Students describe the outlines of the subjects they learn through visuals such as paintings and caricatures. This can be thought of as a contribution of visuals to their own speaking education and contribution of visuals to their listeners' listening/observation education. The act of benefiting from visuals that are presented in texts MEB [28] shows that visuals have a structure supporting reading education, as well. Especially in activities carried out for comprehension, visually supporting students' work facilitates learning. Visual materials as one of the essentials components of a student's cognitive development process are also an effective skill in design and problem-solving activities [29]. Painting and other visual materials are some of the effective materials in the educational environment due to the fact that they have certain aspects that complement ideas in students' minds in the middle school level and they give students aesthetic values [30].

It is using a set of tools use dashes with spaces such as sounds, images, activities, graphics, photographs, puppets, electronic texts and videos used in the classroom environment- to establish meanings and share established meanings [31]. Visual materials improve thinking and understanding text that is read and listened to, and additionally, facilitate the organization of information logically. They especially make it easier to convey meanings of new concepts such as pictures, graphics, shapes, and caricatures. Visual presentation also facilitates organizing information, classifying and sorting concepts [32]. It accelerates the process of students' combining new knowledge with prior knowledge and structuring it in their minds, as well [30].

\subsection{The Problem Statement}

Interactive whiteboards are some of the most effective educational tools that can be used in educational environments due to their superior qualities such as effectiveness, motivation, integrity, continuity, usefulness, multifaceted usage, high speed, reliability and mutual interaction in learning-teaching processes [33]. It is seen that interactive whiteboards enhance students' motivation, attract their attention, and students and teachers have a positive attitude towards interactive whiteboards. Glover and Miller [11] indicate that the use of interactive whiteboards enhances the motivation and interest of elementary and middle school students when teachers use the interactive whiteboards to support the use of different learning styles. Data presented by Becta [4] also show that interactive whiteboards positively affect learning and teaching processes. In education, the use of teaching 
methods that address more than one sense makes learning more persistent. The use of interactive smart boards in the educational process creates opportunities to use different instructional methods in the classroom. Emerging in the 1980s, interactive whiteboards have also been used in other sectors, including education. The optimistic results that have emerged have enabled the widespread use of them, especially in the field of education. Interactive whiteboards are used in $90 \%$ of schools in the UK, Japan and the USA, and $70 \%$ of schools in EU countries [34].

Recent research in the field has shown that the use of interactive whiteboards in lessons enhances student motivation and achievement [35]; [36]; [37]; [34]. The use of technology greatly influences the teaching and learning process. It enhances the effectiveness of teachers in the classroom. Technological designs were made to support students' active participation and interest in the active learning process. Interactive whiteboards provide opportunities for interactive lessons. The use of interactive whiteboards helps students to be more successful.

Visual materials play a major role in directing people, helping them focus their attention, and conducting analyses and syntheses [38]. In the educational process, lectures and presentations carried out using such visual materials can create an effect that plain teaching cannot create alone and can facilitate students' understanding. Visual materials supported by sounds, pictures, caricatures and different animations available within the software of interactive whiteboards provide a more persistent learning and a better ability to remember the subject being taught. Considering that learning is more persistent through vision and hearing, it becomes clear how important interactive whiteboards are when supported by visual materials [39].

In the Turkish course, interactive whiteboards have great importance in terms of improving student motivation. In the 21st century, which we also refer to as the age of science, the advancement and development of technology have led to the emergence of new classroom tools and equipment. As Özbay [40] has emphasized, there is only listening as the comprehension skill until the school age, when the bases of the mother tongue are established at a great extent. In this respect, it can be said that the listening skills form the basis of other language skills [41]. According to research, people spend as much time listening as they spend time reading, writing and speaking [42].

It can be said that in children who start elementary school, communication and learning are based on listening. According to Akyol [42] about $80 \%$ of what we know is learned through listening. In the era of visual literacy, it is important that visual objects are used in Turkish courses and that students are given opportunities to gain this skill.

This study was carried out based on the fact that interactive whiteboard applications as well as the use of visual materials ensure motivation and facilitate learning in the educational process. The problem statement of this study was how the development of listening skills, one of the most important basic language skills and learning areas of middle school students, was affected by interactive whiteboard applications supported by visual materials.

\subsection{Purpose and Significance of the Study}

According to the results of PISA 2015, Turkey had an average of 428 points in comprehension skills based on the average of OECD countries and all countries, and ranked 50th among 72 countries [43]. In order to increase Turkey's average PISA score, the Turkish education system has been undergoing restructuring in itself. In line with the studies done, the system is constantly evolving and renewing. The radical changes that have been made in the elementary and middle school curricula in our country's educational system in recent years have brought a new perspective to the understanding of education in our country.

Turkey is not at the desired level and has failed in international comparative exams such as PISA and TIMSS. Thus, Turkey has made changes to its curricula paralleling the developments in science and technology and the developments in the understanding of the roles of teachers and learning in educational sciences. As is known, modifications that are made must primarily include elements that will improve the quality of instruction; the use of appropriate strategies, methods and techniques; and an effective classroom management, equipment use and evaluation process [44]; [45].

The studies that Turkey has done to raise this success include the integration of the studies to improve the educational use of information technologies into the studies that had been carried out to increase student achievement levels, to foresee the impact of educational policies on students, to make the educational system more functional, and to improve the quality of education [46].

While the use of new technologies in the teaching process is important for all school types and grade levels, it has a privileged position especially in the Turkish courses. The Turkish Course Curriculum prepared by the Ministry of National Education lists the opportunities for teachers and students to use computers and other information and communication technologies in the learning and teaching process. The curriculum also emphasizes the need to utilize these technologies.

In this study, it was aimed to investigate the effect of technological materials - especially the effect of interactive whiteboard applications supported by visual materials - on middle school students' listening comprehension and on raising their academic achievement. In this study, it was also aimed to emphasize the importance of using pictures and photographs, which are indispensable tools of Turkish courses, in activities to develop the students' listening comprehension skills. Moreover, the other factors that make this study important 
include the fact that this study offers a model for the Turkish Course Curriculum to raise Turkey's listening comprehension level in international student achievement examinations like PISA and makes recommendations for the Turkish course teachers to use in their listening studies.

In order to achieve these aims, answers to the following sub-problems were sought.

- Is there a significant difference between the students in the experimental group and the students in the control group in terms of their listening comprehension achievement in the pre-test?

- Is there a significant difference between the students in the experimental group and the students in the control group in terms of their listening comprehension achievement in the post-test?

- Is there a significant difference between the experimental group students' listening comprehension achievement scores obtained from the pre-test and those obtained from the post-test?

- Is there a significant difference between the listening comprehension achievement scores and the persistence test achievement scores of the students in the experiment group in the post-test?

\section{Materials and Methods}

In this section, the following sub-headings related to the research model, the sample and the data collection instrument are presented.

\subsection{Research Method}

This study examined how interactive whiteboard applications supported by visual materials affected the development of listening comprehension skills in middle school students. In addition, the contribution of listening texts supported by appropriate visual objects to listening comprehension was studied. In this study, a pre-test, a post-test and a persistence test were applied, and a control group experimental design was preferred. Experimental studies are research designs in which external variables are controlled to ensure internal validity, dependent variables are measured, and between-variable cause-effect relationships are examined. In this model, participants are evaluated in terms of the dependent variable before and after experimental procedures [47].

\subsection{Research Sample}

Due to the use of the pre-test post-test control group experimental design in the study, information about the experimental groups will be given in this section, instead of the population and sampling. The sample of the study consisted of the students in the 8/D (experimental group $n=36$ ) and $8 / H$ (control group $n=36$ ) cohorts of the Osman Gazi Middle School located in Palandöken central district of Erzurum province during the spring semester of the 2017-2018 school year. The groups were formed through random assignment. There were interactive whiteboards in the classrooms where the study was conducted.

\subsection{Data Collection Instrument}

In line with the aim of the study, in order to determine the effect of interactive whiteboard applications on student success, first the relevant literature was reviewed. Then, by taking the opinions of Turkish educators and Turkish teachers, a "Listening Achievement Test (LAT)" was prepared, which included 20 multiple-choice questions, all of which were asked by the Measuring, Selection and Placement Center of Turkey in various past central exams. The validity and reliability study of the test was carried out on 150 8th grade students studying in different middle schools. In terms of the validity and reliability of the scale, as a result of the analysis, the Cronbach's alpha value was found to be .81 and the KMO (Kaiser-Meyer-Olkin) test result was found to be .623. A Cronbach's alpha value of .81 suggests that the scale was acceptable [48]. This value shows that the test administered in the study was valid and reliable. Data collected during the implementation were analyzed in the SPSS 20 package program. The achievement statuses of the listening comprehension skills of the students in the experimental and control groups were evaluated by running $t$ tests.

\subsection{Implementation Process}

Experimental and control groups were established before starting the study. The LAT test was administered as a pre-test to the experimental and control group students. The course was taught to the students in the control group according to the 2018 Turkish Course Curriculum, which had been rearranged and put into practice. The text "I Want to Be a Teacher" of the Personal Development theme was read aloud only by the teacher to the students in the control group, and the students were asked to do the activities in the workbook.

After LAT was administered as a pre-test to the experimental group, the same listening text was listened to the students by reading aloud using the interactive whiteboard applications. In line with the aims and achievements of listening, visual materials related to the text and appropriate pictures and photographs were shown to the students. After the implementations, LAT, which was administered to both groups as a pre-test, was administered as a post-test. Next, the measurements of the groups were compared after the experiment. Four weeks after the research was completed, the Listening Achievement Test, which was administered as a post-test, was administered again to the students in the experimental group to measure the persistence of learning 
Table 1. Procedures carried out for the Experiment and Control Groups

\begin{tabular}{|c|c|c|c|c|}
\hline Groups & Pre-test & Implementation & Post-test & Persistence Test \\
\hline $\begin{array}{c}\text { Experimental Group } \\
8 / \mathrm{D}(\mathrm{n}=36)\end{array}$ & $\begin{array}{c}\text { Listening Achievement } \\
\text { Test (LAT) }\end{array}$ & $\begin{array}{c}\text { Through interactive } \\
\text { whiteboard applications } \\
\text { supported by visual } \\
\text { materials }\end{array}$ & $\begin{array}{c}\text { Listening Achievement } \\
\text { Test (LAT) }\end{array}$ & $\begin{array}{c}\text { Listening Achievement } \\
\text { Test (LAT) }\end{array}$ \\
\hline $\begin{array}{c}\text { Control Group } \\
8 / \mathrm{H}(\mathrm{n}=36)\end{array}$ & $\begin{array}{c}\text { Listening Achievement } \\
\text { Test (LAT) }\end{array}$ & $\begin{array}{c}\text { According to the } 2018 \\
\text { Turkish Course Curriculum }\end{array}$ & $\begin{array}{c}\text { Listening Achievement } \\
\text { Test (LAT) }\end{array}$ & \\
\hline
\end{tabular}

Table 2. Comparison of pre-test Listening Achievement Test levels of the students in the experimental and control groups

\begin{tabular}{|c|c|c|c|c|c|}
\hline Groups & $\mathrm{N}$ & $\overline{\mathrm{X}}$ & $\mathrm{SD}$ & $\mathrm{t}$ & $\mathrm{p}$ \\
\hline Control Group & 36 & 53.33 & 6.97 & & \\
\cline { 1 - 4 } Experimental Group & 36 & 51.25 & 7.96 & -1.181 & .241 \\
\hline
\end{tabular}

Table 3. Comparison of post-test Listening Achievement Test levels of the students in the experimental and control groups

\begin{tabular}{|c|c|c|c|c|c|}
\hline GROUPS & $\mathrm{N}$ & $\overline{\mathrm{X}}$ & $\mathrm{SD}$ & $\mathrm{t}$ & $\mathrm{p}$ \\
\hline Control Group & 36 & 62.92 & 6.25 & \multirow{2}{*}{7.991} & .000 \\
\hline Experimental Group & 36 & 76.94 & 8.47 & & \\
\hline
\end{tabular}

Table 4. Comparison of the pre-test and post-test levels of students in the experimental group

\begin{tabular}{|c|c|c|c|c|c|}
\hline GROUPS & $\mathrm{N}$ & $\overline{\mathrm{X}}$ & $\mathrm{SD}$ & $\mathrm{t}$ & $\mathrm{p}$ \\
\hline Pre-test & 36 & 51.25 & 7.96 & & \\
\cline { 1 - 4 } Post-test & 36 & 76.94 & 8.47 & -27.41 & .000 \\
\hline
\end{tabular}

\section{Findings}

In this section, findings from the study and interpretations of these findings are given.

Table 2 shows the mean scores of listening comprehension achievement of the students in both groups after the study. The mean LAT score of the students in the control group was 53.33 and that of the students in the experimental group was 51.25. The t value calculated based on the scores of the two groups was -1.181 . The independent samples $t$ test that was carried out to determine whether there was any difference between the groups yielded $p=.241$, which indicated that there was no significant difference between the groups at .05 significance level. This result shows that the achievement levels of the students in the experimental and control groups were close to each other.

According to Table 3, the LAT score of the students in the experimental group, who were taught using interactive whiteboards supported by visual materials, was 76.94, whereas the LAT score of the students in the control group, who were taught according to the 2018 Turkish Course Curriculum, was 62.92. The $\mathrm{t}$ value, which was calculated based on the experimental and control group scores, was 7.991. The independent samples t test that was carried out to determine whether there was any difference between the groups yielded $p=.000$, which indicated that there was a significant difference between the groups at .05 significance level. The source of the resulting difference was the increase in the listening comprehension skills of the students in the experimental group. Based on these findings, it is understood that listening comprehension lessons taught using interactive whiteboards, which were supported by visual materials, constitute an effective model to enhance students listening comprehension levels.

Considering the data in Table 4, the pre-test achievement score of the students in the experimental group was 51.25 before the implementation, while their mean post-test score was 76.94. The t value, which was calculated based on the pre- and post-test scores of the experimental group, was -27.41. The paired-samples t test that was carried out to determine whether there was any difference between the pre-test and post-test yielded $p=.000$, which indicated that there was a difference between the pre-test and post-test scores at .05 significance level. The source of the resulting difference was the increase in the post-test scores of the 
students in the experimental group. Based on these findings, it is understood that the Turkish course taught using interactive whiteboards, which were supported by visual materials, constitute an effective model to enhance students' listening comprehension levels

Considering Table 5, the pre-test score of the control group students was 53.33 while their post-test achievement score was 62.92. The $t$ value, which was calculated based on the control group scores, was -16.621. The paired-samples $t$ test that was carried out to determine whether there was any difference between the pre-test and post-test yielded $\mathrm{p}=.000$, which indicated that there was a significant difference between the pre-test and post-test scores at .05 significance level. The increase between the pre- and post-test scores of the control group by about 9 points can be explained by the fact that the renewed Turkish Course Curriculum was in effect.

Table 5. Comparison of the pre-test and post-test levels of students in the control group

\begin{tabular}{|c|c|c|c|c|c|}
\hline GROUPS & $\mathrm{N}$ & $\overline{\mathrm{X}}$ & $\mathrm{SD}$ & $\mathrm{t}$ & $\mathrm{p}$ \\
\hline Pre-test & 36 & 53.33 & 6.97 & \multirow{2}{*}{-16.621} & .000 \\
\cline { 1 - 4 } Post-test & 36 & 62.92 & 6.25 & & \\
\hline
\end{tabular}

Considering the data in Table 6 , the post-test achievement score of the students in the experimental group was found to be 76.94, and the of the persistence test re-administered 4 weeks later to the students in the experimental group was found to be 75.08. The $t$ value, which was calculated based on the experimental and control group scores, was 2.563 . The paired-samples $t$ test that was carried out to determine whether there was any difference between the groups yielded $\mathrm{p}=.015$, which indicated that there was between the post-test and persistence test scores at .05 significance level.

Table 6. Comparison of the achievement levels of the post-test and persistence test of the students in the experiment group

\begin{tabular}{|c|c|c|c|c|c|}
\hline GROUPS & $\mathrm{N}$ & $\overline{\mathrm{X}}$ & $\mathrm{SD}$ & $\mathrm{t}$ & $\mathrm{p}$ \\
\hline Post-test & 36 & 76.94 & 8.47 & \multirow{2}{*}{2.563} & .015 \\
\cline { 1 - 4 } Persistence & 36 & 75.08 & 7.19 & & \\
\hline
\end{tabular}

\section{Conclusions}

In this study, how visually supported interactive whiteboard applications affected the listening comprehension and persistence of learning of the middle school students was investigated. The research was carried out on the 8th grade students of Osman Gazi Middle School in Palandöken district of Erzurum province in the 2017-2018 school year. Experimental and control groups were established before starting the study. The following results were obtained in the study.
When the pre-test and post-test LAT scores of the experimental and control groups were examined, it was seen that the students in the experimental and control groups received pre-test scores that were close to each other (Control group $(\mathrm{CG})=53.33$ and Experimental group $(E G)=51.25)$. This indicates that the achievement levels of the groups were close to each other, and it was appropriate to begin the study. In the post-test, it was found that the scores of the experimental group students were greater than the scores of the control group students $(\mathrm{CG}=62.92$ and $\mathrm{EG}=76.94)$. This shows that the experimental group students achieved a greater achievement level than the control group students. Moreover, the greater scores of the experimental group in both the post-test and the persistence test can be explained by the teaching of the listening comprehension lessons using interactive whiteboards supported by visual materials. Structuring what was learned in the mind, integrating it, interpreting it and reaching a conclusion, and the facilitation of its repetition show that the lessons that were taught using interactive whiteboards supported by visual materials were effective.

\section{Discussion}

Since the 2005-2006 school year, the new Turkish Course Curriculum, which is based on the constructivist learning approach, has been implemented in Turkey. One of the most salient points in this curriculum is that the education is carried out through activities [45]. It is seen that in today's educational system, in which the constructivist methods are being implemented, interactive whiteboards alone are inadequate to create the desired effect on academic achievement and persistence of learning. Interactive whiteboards will be more effective on academic achievement if supported by a variety of materials and other methods and techniques. Adigüzel et al. [49] have proven that when interactive whiteboards are used regularly and through accurate methods and when they are adapted to courses, they help students better understand abstract concepts that are difficult to learn, help enhance language learning, and help students get motivated for lessons as the interactive whiteboards give them opportunities to practice diverse instructional methods.

The use of interactive whiteboards in listening comprehension studies in Turkish courses motivate students and improve their attendance. Interactive whiteboards are as much effective as different features of them are used. The literature review on the effect of visual materials on learning has shown that the use of visual materials enhances the level of education [50]; [51]. According to Ipek [52] visual materials, paintings, symbols and screen designs facilitate learning and increase permanence in learning. The use of visual and 
audial tools in education is very important in terms of learning new information more easily and persistence of learning. The more senses of an individual a planned learning activity appeals to, the more persistent the learning event becomes. Glover, Miller and Averis [53] have indicated that motivation and engagement of elementary and middle school students increase when interactive whiteboards are used according to different learning styles. Beauchamp and Kennewell [54] have reported that the use of interactive whiteboards, which are an information and communication technology, enhance students' interest in learning. Interactive whiteboards, multimedia presentations and different materials provide positive contributions in interactions, class participation and learning in the classroom [12]. Research has shown that interactive whiteboards enhance meaningful learning,[55], [25]; [45]; and contribute positively to the academic achievement of students during the learning process [56]; [39]; [57]; [58]. These results show similarities to the results of the current study and parallel them.

\section{REFERENCES}

[1] Güzeller, C. ve Korkmaz, Ö. (2007). bilgisayar destekli öğretimde bir ders yazılımı değerlendirmesi. Kastamonu Eğitim Dergisi,15, (1), 155-168.

[2] Oğuz, O., Oktay, A., Ayhan, H.,(2004), 21.Yüzyılda eğitim ve Türk eğitim sistemi, İstanbul: Değerler Eğitimi Merkezi Yayınları.

[3] İşman, A. (2005). Öğretim Teknolojileri ve Materyal Geliştirme. 2. Baskı, Ankara: Pegem Yayıncılık.

[4] Becta (British Educational Communications and Technology Agency) (2004), Getting the Most from Your Interactive Whiteboard: A Guide For Primary Schools. http://39lu337z5111zjr1i1ntpio4.wpengine.netdnacdn.com/ wpcontent/uploads/2016/04/getting_most_whiteboard_pri mary.pdf. Retrieved: 16.05.2018.

[5] Levy, P. (2002). Interactive whiteboards in learning and teaching in two sheffield schools: a develompmental study, sheffield: Department of Information Studies, University of Sheffield.

[6] Rivers, G. (2009). Interactive whiteboards in third grade science instruction, Thesis (Ph.D.), Nova Southeastern University.

[7] Yalın, H. (2010). Öğretim Teknolojileri ve Materyal Geliştirme. 22. Baskı, Ankara, Nobel Yayın Dağıtım.

[8] Altınçelik, B. (2009). Matematik öğretiminde akilli tahta kullaniminin 10. sinif öğrencilerinin akademik başarilari, matematik dersine karşi tutumlari ve öz 51 yeterlik düzeylerine etkileri, (Yayınlanmış Yüksek lisans tezi), Sakarya Üniversitesi, Sosyal Bilimler Enstitüsü, Sakarya.

[9] Bell, M. A. (2002). Teacher feature: Why use an interactive whiteboard? A baker's dozen reasons!
Teachers.net Gazette, 3(1). http://teachers.net/gazette/JAN0 2/mabell.html Retrieved: 21.05.2018.

[10] Brown, S. (2003). Interactive whiteboards in education. Joint Information Systems Committee Technology Centre. Retrieved:http://www.jisc.ac.uk/uploaded_documents/Inter activewhiteboards.pdf.

[11] Glover, D., Miller, D., Averis, D., \& Door, V. (2007). The evolution of an effective pedagogy for teachers using the interactive whiteboard and modern languages: An empirical analysis from the secondary sectors. Learning, Media and Technology, 32 (1), 5-20.

[12] Smith, H, J., Higgins, S., Wall, K. \& Miller, J. (2005). Interactive whiteboards: boon or bandwagon? A critical review of the literature. Journal of Computer Assisted Learning, 21, pp 91-10

[13] Öztan, A. C. (2012). Fen ve teknoloji öğretiminde akıllı tahta kullanımının İlköğretim 7. sınıf öğrencilerinin akademik başarılarına etkisi, Necmettin Erbakan Üniversitesi Eğitim Bilimleri Enstitüsü İlköğretim Anabilim Dalı Fen Bilgisi Eğitimi Bilim Dalı, Konya.

[14] Kırbaș, A. (2018). Student Views on Using Smart Boards in Turkish Education, Universal Journal of Educational Research 6(5): 1040-1049.

[15] Minor, B., Bracken, M., Geisel, P., Unger, S. (2006) Smart boards in the classroom: The Influence of interactive boards in education, http://tiger.towson.edu/users/sunger2/ smart_boards_in_the_classroom.htm

[16] Starkings, S., \& Krause, L. (2008). "Chalkboard to smartboard - maths going green?" MSOR Connections, 7(4), 13-15.

[17] Kazu, H. ve Yeşilyurt, E. (2008): .Öğretmenlerin öğretim araç-gereçlerini kullanım amaçları., Fırat Üniversitesi Sosyal Bilimler Dergisi, 18(2), 175-188.

[18] Çiftçi S., Taşkaya S. and Alemdar M. (2013): .Sınıf Öğretmenlerinin Fatih Projesine ilişkin Görüşleri., Elementary Education Online, 12(1), 227-240.

[19] Yegen, Ü. (2014). Ortaokul öğrencilerinin konuşma becerilerinin geliştirilmesinde görsellerin etkisi, (Yayınlanmış Yüksek lisans tezi), Dumlupınar Üniversitesi Eğitim Bilimleri Enstitüsü Türkçe Eğitimi Ana Bilim Dalı, Kütahya.

[20] Ocak, İ. Islak, F, G., Ocak, G. (2012). İlkokul 4. sınıf fen bilimleri dersinde kavram karikatürü kullanımının akademik başarıya etkisi, Bartın Üniversitesi Eğitim Fakültesi Dergisi XIV. Uluslararası Katılımlı Sınıf Öğretmenliği Eğitimi Sempozyumu (21-23 May 2015) Özel Sayıs1, 119 - 132.

[21] Dursun, F. (2006).Öğretim Sürecinde Araç Kullanımı. İlköğretmen Dergisi. 1, 8-9.

[22] Akkaya, A. (2013). Türkçe derslerinde ders kitabı dıșında görsel öge kullanmaya ilişkin türkçe öğretmenlerinin görüşlerinin incelenmesi, Turkish Studies - International Periodical For The Languages, Literature and History of Turkish or Turkic Volume 8/9 Summer 2013, p. 471-479.

[23] Dursunoğlu, H. (2010). Some visuals that can be utılized for making the sound understand intuitively it in primary readıng and wrıtıng educatıon, Erzincan Eğitim Fakültesi 
Dergisi Cilt-Say1: 12-1, 91-105.

[24] Kıran, I. (2008). İlköğretim 5. sinıf öğretmen ve öğrencilerinin görsel okuryazarlıkları üzerine bir araştırma. Yüksek Lisans Tezi, Çanakkale Onsekiz Mart Üniversitesi Sosyal Bilimler Enstitüsü İlköğretim Bölümü İlköğretim Anabilim Dalı Sınıf Öğretmenliği Bilim Dalı Çanakkale.

[25] Akkaya, A. (2011). Karikatürlerle dil bilgisi öğretimi, selçuk Üniversitesi Eğitim Bilimleri Enstitüsü Türkçe Eğitimi Ana Bilim Dalı Türkçe Eğitimi Bilim Dalı,Konya.

[26] Klammer, S., R., Newman, M., W., Farrell,R., Bilezikjiann, M. \& Landay, J., A., (2001). The Designers Outpost: A Tangmble Interface for Collarative Web Site Design. Proceedings of the 14th annual ACM symposium on User interface software and technology.http://portal.acm.org/cita tion.cfm?id $=502350$

[27] Lewin, C., Somekh, B. ve Steadman, S. (2008). Embedding interactive whiteboards in teaching and learning: the process of change in pedagogic practice, Education and Information Technologies, 13, 291-303.

[28] MEB (2009). İlköğretim Türkçe Dersi Öğretim Programı ve Kılavuzu (1-5. Sinıflar). Ankara: MEB Yayınları.

[29] Robertson, M. S. (2007). Teaching visual literacy in the secondary english/languagearts classroom: an exploration of teachers' attitudes, understanding and application.(Unpublished doctorol thesis). Kansas State University: USA.

[30] Ediş, S. (2000). İlköğretim altıncı sınıf Türkçe kitaplarında resimleme-metin ilişkisi, Yüksek Lisans Tezi, Marmara Üniversitesi Sosyal Bilimler Enstitüsü, İstanbul.

[31] Akyol, H. (2008). Yeni Programa Uygun Türkçe Öğretim Yöntemleri (2. Baskı). Ankara: Kök Yayıncılık.

[32] Güneş, F. (2007). Türkçe Öğretimi ve Zihinsel Yapılandırma. Ankara: Nobel Yayın ve Dağıtım.

[33] PAINTER, D., Whiting, E., Wolters, B. \& Park, D. (2005). "The Use of an Interactive Whiteboard in Promoting Interactive Teaching and Learning".

http://gse.gmu.edu/assets/docs/tr/interactive-board_tr.pdf

[34] Akgün, M. (2014). Matematik dersinde ak1llı tahta kullanımına yönelik öğrenci tutumu ve öğretmen görüşlerinin incelenmesi, Yüksek Lisans Tezi, Gazi Üniversitesi Eğitim Bilimleri Enstitüsü İlköğretim Ana Bilim Dalı Matematik Öğretmenliği Bilim Dalı, Ankara.

[35] Asmar M., Khaled, H., Nabeel, A. (2012), The Effect of Smart Board on Students Behavior and Motivation; UGRU University Al Ain, UAE.

[36] Kaya, G. (2013). Matematik Derslerinde Akıllı Tahta Kullanımının Öğrencilerin Dönüşüm Geometrisi Üzerindeki Başarılarına Etkisi. Yayımlanmamış Yüksek Lisans Tezi, Gazi Üniversitesi Eğitim Bilimleri Enstitüsü, Ankara.

[37] Gençoğlu, T. (2013). Geometrik cisimlerin yüzey alanlari ve hacmi konularinin öğretimde bilgisayar destekli öğretim ile akilli tahta destekli öğretimin öğrenci akademik başarisina ve matematiğe ilişkin tutumuna etkisi Yayımlanmamış Yüksek Lisans Tezi, Gazi Üniversitesi Eğitim Bilimleri Enstitüsü, Ankara.
[38] Önder, R. (2015). Biyoloji dersinde akıllı tahta kullanımının öğrencilerin akademik başarılarına, akıllı tahta kullanımına ve derse yönelik tutumlarına etkisi, Yüksek Lisans Tezi, Dokuz Eylül Üniversitesi Eğitim Bilimleri Enstitüsü Bilgisayar Ve Öğretim Teknolojileri Eğitimi Anabilim Dalı Bilgisayar ve Öğretim Teknolojileri Öğretmenliği Programı, İzmir.

[39] Ekici, F. (2008). Akıllı Tahta Kullanımının İlköğretim Öğrencilerinin Matematik Başarılarına Etkisi. Yayınlanmamış Yüksek Lisans Tezi, Marmara Üniversitesi Eğitim Bilimleri Enstitüsü, İstanbul.

[40] Özbay, M., (2005). Bir Dil Becerisi Olarak Dinleme Eğitimi. Ankara: Akçağ Yayınları.

[41] Karasakaloğlu, N., Bulut, B. (2012). Görsel destekli dinleme metinlerinin anlamaya etkisi, e- Journal of New World Academy, Volume: 7, Number: 2, 722-733.

[42] Akyol, H., (2010). Yeni Programa Uygun Türkçe Öğretim Yöntemleri (3. baskı) Ankara: Pegem Akademi Yayıncılık.

[43] MEB (2016). Uluslararası öğrenci değerlendirme programı P1sa 2015 Ulusal raporu, Millî eğitim Bakanlığı Ölçme, Değerlendirme ve Sinav Hizmetleri Genel Müdürlügü, Ankara.

[44] Üstündağ, T., Ayvaz, Z., Tuncel, İ. ve Çobanoğlu, F. (2008). İlköğretim 2. Sinıflarda Öğrenme Öğretme Sürecinin Betimlenmesine İlişkin Durum Çalışması. İlköğretim Online. 7 (2), 349-360.

[45] Türkoğlu, T. (2014). Fen ve teknoloji öğretiminde akıllı tahta kullanımının 6. sınıf öğrencilerinin akademik başarı, tutum ve görüşleri üzerine etkileri, Yüksek Lisans Tezi, Celal Bayar Üniversitesi Fen Bilimleri Enstitüsü Fen Bilimleri Eğitimi, Manisa.

[46] Çelen, F. K., Çelik, A. ve Seferoğlu, S. S. (2011). Türk Eğitim Sistemi ve PISAvSonuçları. XIII. Akademik Bilişim Konferansı, 765-773, İnönü Üniversitesi, Malatya.

[47] Büyüköztürk, Ş., (2007). Deneysel Desenler (2. bask1) Ankara: Pegem Akademi Yayıncılık.

[48] Ünal, K. (2015). Ortaöğretim Kurumlarında Tarih Öğretiminde Akıllı Tahta Kullanımına Yönelik Öğrenci Görüşleri, (yayımlanmamış yüksek lisans tezi). Gazi Üniversitesi Eğitim Bilimleri Enstitüsü Ankara.

[49] Adıgüzel, T., Gürbulak, N., Sarıçayır, H. (2011). Smart boards and their instructional uses, Mustafa Kemal University Journal of Social Sciences Institute Volume: 8, Issue: $15,457-471$

[50] Stokes, S. (2002).Visual literacy in teaching and learning: a literature perspective. Electronic Journal for the Integration of Technology in Education, 1 (1), 10-19.

[51] Tiemensma, L. (2009). Visual literacy: To comics or not to comics? Promoting literacy using comics. World Library and Information Congress: 75th Ifla General Conference and Counc1l. 23-27 Milan, Italy.

[52] İpek,İ. (2003). The Turkish Online Journal of Educational Technology, Bilkent Üniversitesi, 2(3), 125,134. ISSN: $1303-6521$

[53] Miller, D., Glover, D. ve Averis, D. (2005). Developing Pedagogic Skills for the Use of the Interactive Whiteboard 
in Mathematics, British Educational Research Association.

[54] Kennewell, S. \& Beauchamp, G. (2007). The features of interactive whiteboards and their influence on learning. Learning, Media and Technology. 32(3), 227-241.

[55] Tataroğlu, B. (2009). Matematik Öğretiminde Akıllı Tahta Kullanımının 10 Sınıf Öğrencilerinin Akademik Başarıları, Matematik Dersine Karşı Tutumları Ve Öz-Yeterlik Düzeylerine Etkileri. Yayınlanmamış Yüksek Lisans Tezi. Dokuz Eylül Üniversitesi, İzmir.

[56] Akdemir, E. (2009). Akıllı tahta uygulamalarının öğrencilerin coğrafya başarıları üzerine etkisinin incelenmesi, Yüksek lisans tezi, Zonguldak Karaelmas Üniversitesi Sosyal Bilimler Enstitüsü. Zoguldak.

[57] Akçayır, M. (2011). Akıllı Tahta Kullanarak İşlenen Matematik Dersinin Sınıf Öğretmenliği Birinci Sınıf Öğrencilerinin Başarı, Tutum ve Motivasyonuna Etkisi. Yüksek Lisans Tezi, Gazi Üniversitesi Eğitim Bilimleri Enstitüsü, Ankara.

[58] Şen, M., (2013). İlköğretim birinci kademe İngilizce öğretiminde akıllı tahta kullanımının öğrenci başarısına etkileri, Yüksek Lisans Tezi, İstanbul Üniversitesi, Eğitim Bilimleri Enstitüsü ilköğretim Ana Bilim Dalı Sınıf Öğretmenliği Programı, İstanbul. 